\title{
Editorial - Investor activism and corporate responsibility
}

\section{Introduction}

The growing exposure of Western companies to difficult and relatively unregulated developing world business environments has created a major challenge for global multinationals. Companies operating in developing countries often face acute problems associated with poverty, disease, corruption, conflict and the abuse of human rights. These problems are frequently exacerbated by the weaknesses in developing country governments, which means that they are often unable or unwilling to provide the strong regulatory supervision that guides and constrains business activities in the developed countries.

While it has always been possible to find some fund managers with an understanding of the commercial relevance of environmental and ethical issues, the reality has been that, for most asset managers, matters of corporate responsibility have not enjoyed much of a profile. The major exceptions have been the 'ethical' investment market and those specific situations where an ethical or an environmental issue becomes so obviously material to the business that it cannot be ignored. The Myners report, the collapse of Enron and a persistent bear market, however, have woken even the sleepiest of shareholders to the need to play a more active role in the governance of companies. Despite these events, the activist agenda defined for shareholders by the Combined Code of the Committee on Corporate

Governance $^{1}$ remains surprisingly narrow. More specifically, the Combined Code is silent on ethical questions such as the actions that shareholders should take in situations such as when their companies are paying bribes or sourcing from supply chains in which unpleasant forms of child labour are common.

\section{What responsibilities? What standards?}

Our view is that, where companies face ethical issues such as child labour, bribery and corruption, human rights violations and environmental degradation, shareholders should take an active interest in these questions. Some might think that this view is somewhat academic, given that it has been hard enough to get shareholders to become activist with regard to corporate governance when their own rights and financial interests are directly at stake. Surprisingly enough, such cynicism is misplaced. For reasons both of customer demand and regulatory encouragement, a substantial number of large institutional shareholders are already actively engaged with companies on issues of corporate responsibility. In London alone, there are now perhaps 50 analysts working 
specifically in this topic in investment institutions on behalf of perhaps ¿300bn of assets. Individual investment institutions have begun to do useful work to encourage companies to improve their practices with regard to a range of issues - climate change, environmental reporting, sweatshops and child labour, access to medicines and human rights. This activity has often been effective, and has been welcomed by companies and their critics alike.

To date, however, investor activity has been hampered by the lack of a clear, shared view of what standards shareholders should expect of their companies. The most obvious answer is that companies should obey the law. This is not as trite or as simple as it sounds. In developed countries, the abundance of hard-won regulatory protection for employees, for consumers, the environment and for the public means that, if companies obey the letter and the spirit of the law, they should simultaneously meet their central corporate responsibilities. Obviously, law is not a perfect guide to corporate responsibility, as the law does not cover every ethical challenge, and some laws are bad laws.

Nevertheless, in the main, the law provides an obvious and authoritative background of standards, against which shareholders and others can evaluate corporate responsibility.

Unfortunately, reliance on the law is not effective where it is, perhaps, most needed (ie in developing countries). So, in the absence of regulation, should shareholders define their 'own' standards for companies? While shareholder activism on corporate responsibility is of growing importance, it is in everyone's interest that such activism is based on a coherent and legitimate set of standards. In the absence of a 'combined code' on corporate responsibility, our view is that the most credible basis for such standards is the framework provided by international law, in particular those instruments that have been established by the United Nations and widely ratified by governments. The most important of these are the Universal Declaration of Human Rights (UDHR) ${ }^{2}$ and the Rio Declaration on Environment and Development ${ }^{3}$ (and the associated conventions on climate change and biological diversity).

What makes the application of these principles to companies problematic is that international law has almost exclusively concerned itself with the responsibilities of governments, with the assumption being that national governments will then ensure the performance of companies operating within their national boundaries. The consequence is that the expectations of companies are by no means self-explanatory. There has, however, been progress in certain areas. For example, the UN Sub-Commission on the Promotion and Protection of Human Rights has recently issued its 'Draft Norms on Responsibilities of Transnational Corporations \& Other Business Enterprises with Regard to Human Rights'. ${ }^{4}$ More broadly, both the OECD Guidelines for Multinational Enterprises, ${ }^{5}$ and the International Labour Organisation's Tripartite Declaration of Principles Concerning Multinational Enterprises and Social Policy, ${ }^{6}$ provide important first steps in codifying the social and environmental expectations of companies.

\section{Rethinking the risk management approach to corporate responsibility ...}

Using standards such as the UDHR to assess corporate performance moves investors a significant step further than 
the risk-management approach to corporate responsibility envisaged by initiatives such as the ABI's Disclosure Guidelines on Social Responsibility. ${ }^{7}$ These guidelines require companies to disclose their most commercially significant social, ethical and environmental risks and opportunities, and their approach to risk management in this area. While the risk management approach to corporate responsibility is a valuable step forward, it does not establish substantive standards against which investors can measure corporate responsibility.

Nevertheless, standards are needed. Companies want (and need) to know what standards of behaviour they should aim to achieve. When faced by conflicting demands from pressure groups, customers, suppliers, governments and shareholders, companies want to know when there is a genuine obligation for them to go further in addressing a problem, and when they can legitimately say 'enough is enough'.

Greater clarity about the standards of corporate responsibility is, in fact, an essential complement to the risk approach advocated by the ABI. This is because, where corporate responsibility is concerned, there is a very tight relationship between risks and standards. Companies face the greatest corporate responsibility-related risks when their behaviour is out of line with the standards of behaviour that are considered legitimate. These risks are both to reputation (when companies breach the standards which are considered legitimate by their customers or other commercially significant stakeholders) and legal (when companies breach standards which are considered legitimate by the courts). Risk management relating to corporate responsibility cannot proceed very far without clarity about standards.

\section{Is there a business case?}

It is not in the long-term financial interests of companies and their shareholders for these uncertainties about the rights and wrongs of corporate behaviour to persist. What is at stake is not just the immediate corporate reputation impacts, but also the company's long-term 'licence to operate'. That is, the public and political acceptance that underpin the security and stability of investments and markets may also be challenged.

In company law, the board of directors is appointed by the shareholders with a fiduciary duty to serve their interests. The creation of shareholder value is a legal imperative. It is also a very practical requirement, as the failure to provide acceptable returns to investors can lead to plummeting share prices and the dismissal of chief executives. These facts mean that shareholders have both substantial powers over companies and considerable responsibility for what companies do in their name. Our view is that investors have a moral obligation and a compelling long-term financial interest in providing support and encouragement to companies in their efforts to comply with ethical principles based on the authoritative international norms. In this context, shareholders must also be prepared to hold companies accountable for their compliance with these norms. This burden of responsibility has particular force with regard to investments in companies with developing country exposure. Just as companies carry heavier burdens in fulfilling their responsibilities in developing countries, investors too have more work to do in these circumstances.

While moral responsibility provides reason enough for investors to play a role in encouraging corporate responsibility, investors also have long-term interests in encouraging principled business conduct. 
There are two broad reasons for this. The first is that a failure to comply with widely accepted ethical principles is a source of business risk. A series of high-profile controversies relating to corporate activities in the developing world have damaged corporate reputations, led to consumer boycotts and legal action, and undermined the morale and motivation of company employees. Although difficult to quantify in financial terms, such impacts have been widely reported by the companies themselves and have led to significant shifts in their ethical and political strategies.

Furthermore, the long-term prosperity of companies ultimately rests upon a favourable and stable political, legal and regulatory climate. In the West, a number of entire business sectors, including, for example, the construction of new nuclear power stations and, at least in Western Europe, the use of genetically modified crops, have been severely undermined by intense public and political opposition. For all these reasons, ensuring that companies comply with accepted ethical standards ought to be viewed by companies, and encouraged by investors, as an essential tool for managing the financial risks associated with social, environmental and ethical issues. While achieving high standards of corporate responsibility may involve modest costs for the companies in the short term, such strategies can help reduce the risk of a worse fate in the future.

The second reason why investors have a direct interest in encouraging corporate responsibility relates to the sustainability of free-market globalisation as a whole. It is clearly in investors' interests that the broad trend of market and trade liberalisation should continue. Most large Western companies are dependent upon economic growth and investment in developing countries to fuel a significant part of their own future expansion. It is, however, far from certain that this trend will continue inexorably into the future. The 'anti-globalisation' movement has already raised doubts in the minds of many people, including some in positions of political power, about the benefits of continued waves of foreign investment.

Nor are moves towards further economic liberalisation set in stone in many developing countries. China, for example, continues to welcome foreign investors, whereas India remains somewhat suspicious of foreign investors and, in parts of Latin America, there has been a positive upsurge of protest against the perceived effects of economic openness and liberalisation. Ensuring that companies meet certain ethical standards is not a panacea for the problem. To the extent that they reduce the frequency of irresponsible behaviour on the part of Western companies, however, they can help protect the existing political consensus in favour of more foreign investment. In this context, investors have a direct, long-term interest in supporting the promulgation and implementation of these principles across the corporate world.

\section{Conclusions}

Investors have a responsibility, an interest and a substantial opportunity to play a powerful role in encouraging more responsible business practice. We do not underestimate the challenge of moving towards something like a 'Combined Code of Corporate Responsibility'. Nevertheless, without a common framework around which investors can legitimately hold companies accountable, it will be hard for us to make the same rapid progress on corporate ethics issues that we have been able to make on corporate governance issues in recent years. It is defining and implementing such a framework that represents the 
next challenge in the corporate governance debate.

Craig Mackenzie Head, Investor Responsibility Insight Investment Rory Sullivan

Director, Investor Responsibility Insight Investment

\section{Notes}

1 http://www.fsa.gov.uk/pubs/ukla/lr_comcode.pdf

2 http://www.un.org/Overview/rights.html

3 http://www.unep.org/unep/rio.htm

4 http://www.unhchr.ch/Huridocda/Huridoca.nsf/ 0/971d73502dd31b7bc1256c1e00533042/\$FILE/ G0215007.pdf

5 http://www.oecd.org/pdf/M00021000/ M00021070.pdf

6 http://www.ilo.org/public/english/standards/norm/ sources/mne.htm

7 http://www.ivis.co.uk/pages/gdsc7_1.html 